\title{
THE CENTRAL BI-OCEANIC RAILWAY CORRIDOR
}

\author{
Javier Guzmán1,*
}

\begin{abstract}
In this paper it is discussed the Central Bi-Oceanic Railway Corridor called as "The Panama Canal of the $21^{\text {st }}$ Century" Project that will join the Pacific and Atlantic Oceans in South America linking Brazil, Bolivia and Peru. Its impact is expected to be huge, firstly expanding trade and reducing the transport times around 30\%, increasing efficiency and reducing costs.
\end{abstract}

Keywords

Bi-Oceanic, Railway Corridor, South America, Travel Time and Cost Reduction.

\section{INTRODUCTION}

So immense could be its impact in the Region that has deserved "The Panama Canal of the Twenty First Century" sobriquet.

The aim of this paper is to introduce this planned railway corridor and to discuss basic presumptions for its realization and to discuss advantages and drawbacks.

The Corridor will join the Pacific and Atlantic Oceans, involving Peru, Bolivia and Brazil, going from the Port of Ilo in Peru to the Port Santos in Brazil, crossing around $3.750 \mathrm{~km}$ and traversing a splendid landscape: the eternally snowy mountains of the Andes, valleys and the Amazon rainforest, wetlands and savanna plains. Splendid indeed but a great challenge for engineering, a line going from the sea level uphill to 4.000 meters above and back down again to the sea, see Fig. 1.

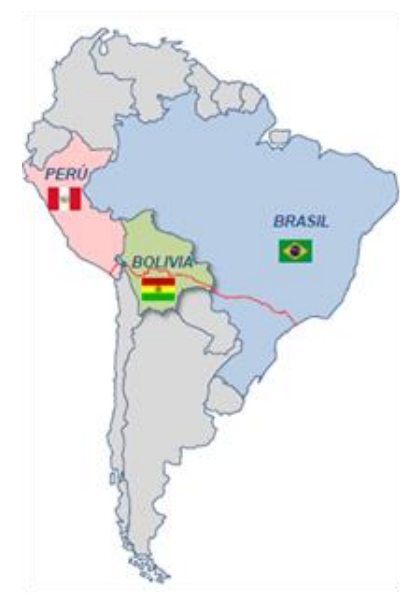

Figure 1 Corridor Scheme. Source: doplayer.es

\footnotetext{
${ }^{1}$ University of Pardubice, Faculty of Transport Engineering, Department of Transport Technology and Control, Studentská 95, CZ-53210 Pardubice, Czech Republic

Corresponding author: e-mail: jaguzman@iom.int
} 
The "Ever Given Tragedy" on Suez Canal in March 2021, with the stranded ship, one of the largest containers ship in the world shut down the Egyptian canal. This canal and related operational conditions are comparable with the conditions in South America. The details and consequences of this accident are not going to be analyzed in this article, all that can be said is, that it has made evident the urgent need of alternatives for trade around the globe. Distribution of traffic flows into more traffic routes can be helpful for stability and flexibility of operation.

\section{TRANSPORT POTENTIAL}

There is a huge potential in this corridor, would permit increase the trade between the countries in the Region and improve the quality of commercial relations with other continents. The first estimations state that transport time could be reduced on $30 \%$; and cargo capacity could increase to 10 million tons a year.

In the passenger market the railways face stiff competition from road transport above all based on cost and time reduction that could be countered with higher quality and comfort services or exclusively oriented to luxury tourism.

Most of the action will take place in Bolivia, where will be two main pillars of financial support for the project and the largest source of cargo. On the oriental side, "El Mutúm" an iron ore deposit near the border with Brazil with an area of around 75 square kilometers with estimated reserves of about 40.200 billion tons of iron ore 50\% iron. And on the Occidental side, "Uyuni Salt Flat" a prehistoric lake that dried out by evaporation with an area of more than 10.500 square kilometers containing an estimated of the $7 \%$ of worlds lithium resources about 9 million tons. All this wealth, could be lost for a lack of development strategies and an appropriate transport system, an efficient one; safe; environmentally friendly with the lowest external costs. The best choice, undoubtedly, a "Proper Railway System".

The "Mutúm", for instance, could generate, during the first five years of the corridor operations, an annual freight of 18.000 .000 tons, almost a 50.000 tons/day what in the present conditions would mean 10 trains a day, to be transported approximately 2.000 kilometers on the direction Est-West in 37 hours with an average speed of $54 \mathrm{~km} / \mathrm{h}$. On the other direction West-Est it is expected to be transported from Uyuni to Santos around 2.000.000 tons/year.

\section{GEOLOGY}

The Geology corresponding to the "Central Bi-oceanic Railway Corridor" presents a variety of changes throughout the entire planned layout. Travelling from West to East, starting the journey on the Peruvian coast (city and harbour of Ilo) and crossing laterally the entire South American continent going through Peru, Bolivia and Brazil, eventually arriving to Santos Seaport in the Atlantic coast in Brazil.

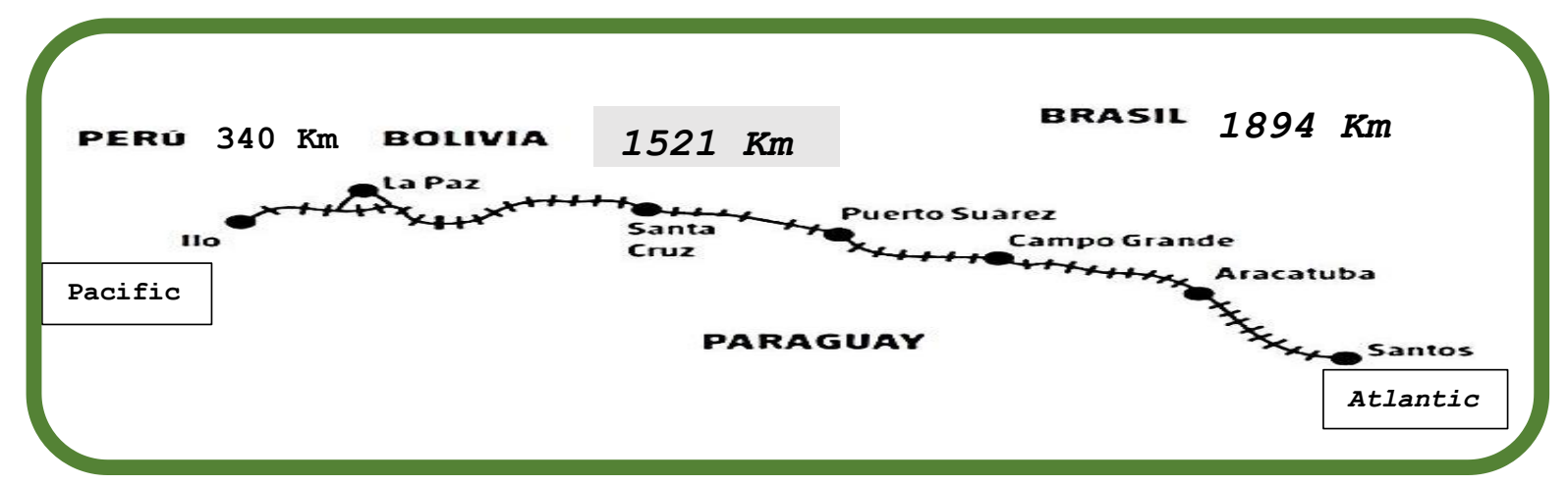

Figure 2 The Bi-Oceanic Railway Corridor through South America, $3750 \mathrm{Km}$. Source: Author 


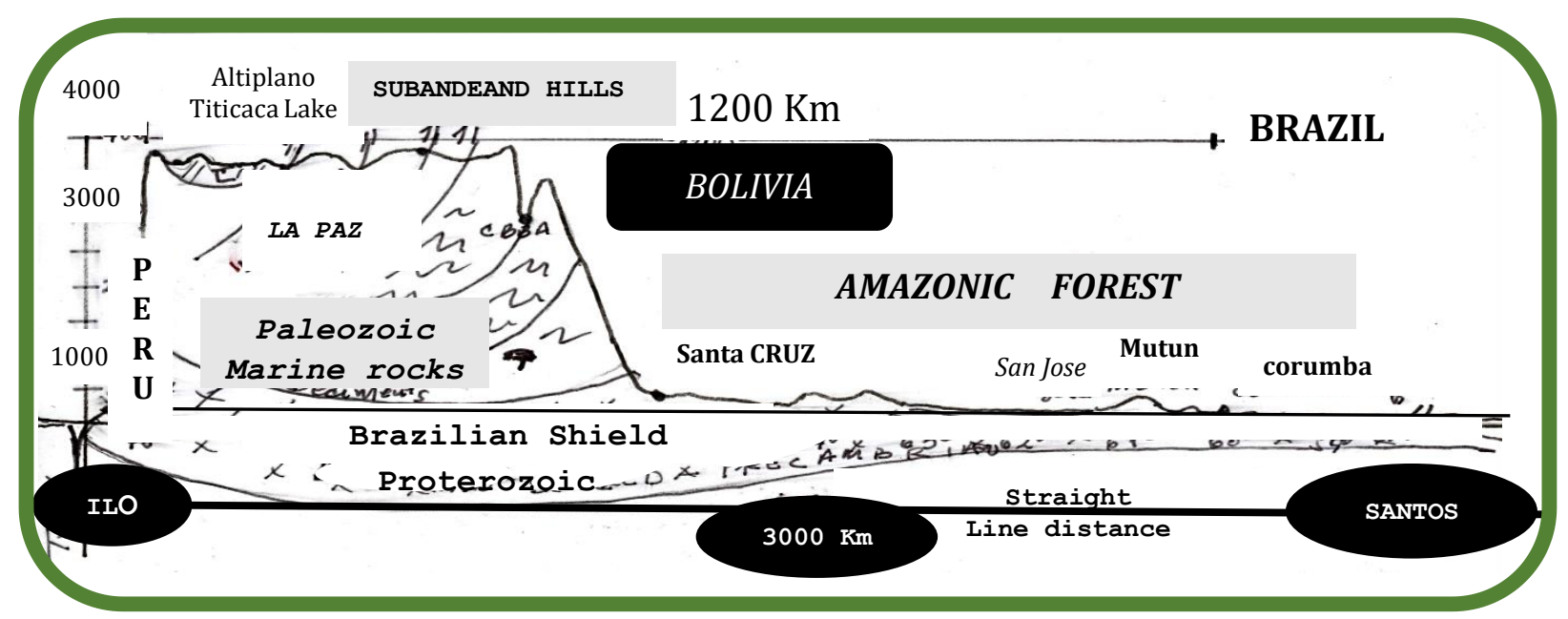

Figure 3 Cross section showing the altitude, the geology and tectonics features. Source: Author based on the research from Ing. Jose Luis Telleria PhD

The cross section shows the heights that the railroad must travel, from $0 \mathrm{~m}$ in the Peruvian Harbour of Ilo to $4000 \mathrm{~m}$ in the high areas in Bolivia, and finally in Santos Harbour in Brazil. The geological terrains are ages since 3000 million years (Brazilian Shield, Precambrian) until de quaternary sediments (all the geological scale). The cross section shows also the folded Palaeozoic strata in Bolivia whit many reverse faults in Sub Andean Hills (rich in oil and gas reservoirs). The line of the corridor will be constructed over sedimentary materials from the Quaternary, below of these are the Palaeozoic rocks (sandstones, shales and metamorphic in the Amazonian region).

The morphology and the orogeny were controlled by the subduction of the Nazca Plate below the Ilo Trench $(5 \mathrm{~km})$. The plate moves under the continent ( $4 \mathrm{~cm} /$ year) since 90 million years ago and already elevated the Andes Belt. After the mountains we have the Amazonian Forest, finally the Atlantic Ocean in Brazil coast.

\section{STATE-OF-ART SITUATION IN TRANSPORT IN THE AREA}

The Railway System in South America in general requires a profound change and a great technological leap, even though Brazil and Argentina have built recently some modern lines. The variety of gauge types, the very few electrified lines, the single lines that limited speeds and crossings. 
Table 1 Length of railway lines in South America. Source: Latin American Railway Association.

\begin{tabular}{|c|c|c|c|c|c|c|c|}
\hline \multicolumn{8}{|c|}{ South American Railway System } \\
\hline \multirow{2}{*}{\multicolumn{2}{|c|}{ Country }} & \multicolumn{5}{|c|}{ Gauge [mm] } & \multirow{2}{*}{$\begin{array}{l}\text { Total } \\
{[\mathrm{Km}]}\end{array}$} \\
\hline & & 1676 & 1600 & 1435 & 1000 & 760 & \\
\hline Argentina & \multirow{9}{*}{ 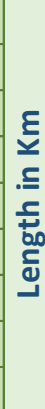 } & 20584 & & 5727 & 10655 & & \multirow{9}{*}{$\underset{\infty}{\stackrel{ }{二}}$} \\
\hline Bolivia & & & & & 3628 & & \\
\hline Brasil & & & 3472 & 3164 & 25784 & 202 & \\
\hline Colombia & & & & 1663 & & & \\
\hline Ecuador & & & & & 966 & & \\
\hline Peru & & & & 2020 & & & \\
\hline Paraguay & & & & 38 & & & \\
\hline Uruguay & & & & 3005 & & & \\
\hline Venezuela & & & & 236 & & & \\
\hline
\end{tabular}

The situation in Bolivia is particularly complex, there are two railway systems that are not interconnected and this issue has been on debate for more than 100 years. Several projects to connect these systems have failed, above all due to political reasons, governments prioritized the development of the road network with an erroneous concept of modernity.

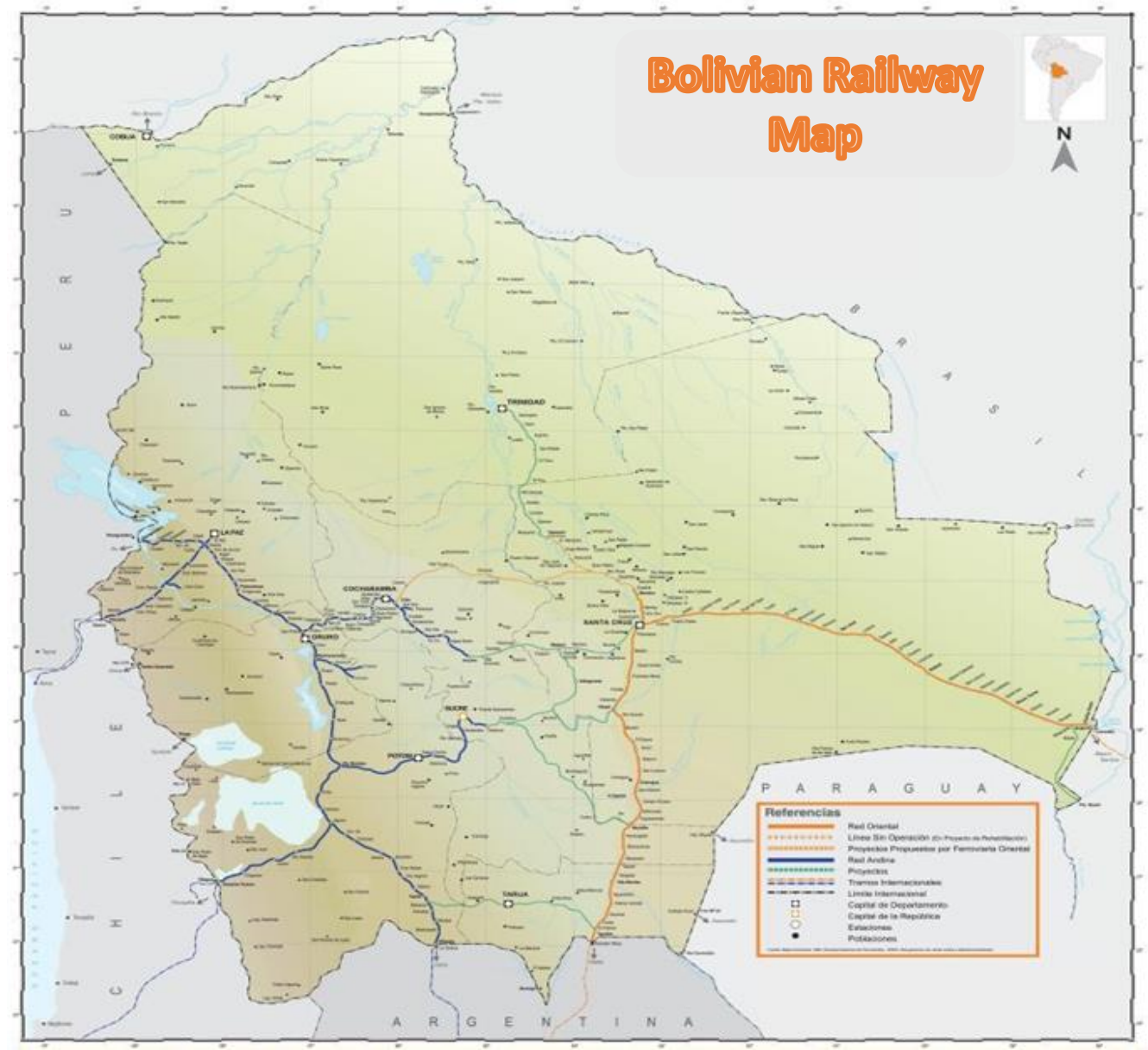

Figure 4 Bolivian Railway System. Source: Energy Press, RDC

Technically backwards the Bolivian railway system would be enhanced only if the "Central Bi-oceanic Railway Corridor" become a reality in the near future. Standards applied on corridor as a backbone line could become a base for future development and integration of all railway systems in the region in spite of the fact that improving of state-of-art networks can be a long-lasting, complex as well as complicated 
process. That will solve in first instance the Interconnection issue and should necessarily adopt modern technologies as shown in the following graphic:

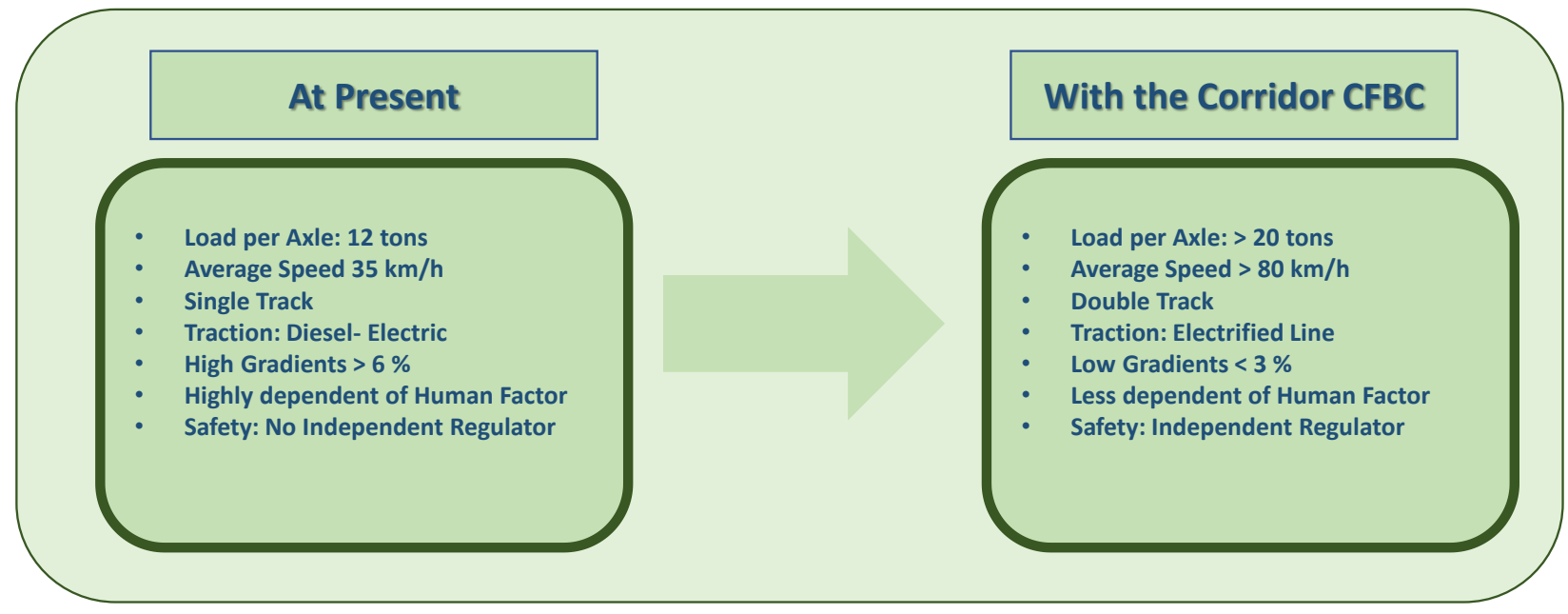

As far as Brazil is concerned, according to https://www.worldexports.com the great portion of its exports (its total 209.8 billion us $\$$ ) by value are sent to:

- Asian countries $53 \%$

- Europe $17 \%$

- $\quad$ North America $15 \%$

as a consequence of this fact the main interest for Brazil in this project is related with cost and time reductions to reach these markets, it is evident that the maritime route through the Pacific Ocean to the Asian countries is the shortest and most direct.

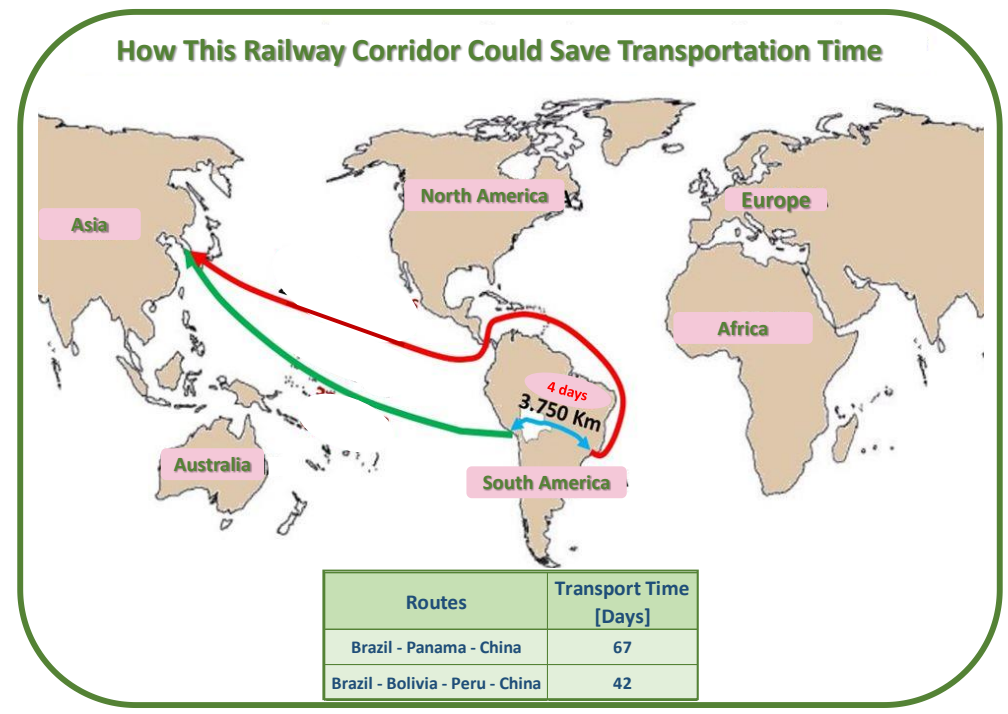

Figure 5 Travel Times Scheme. Source: FC Central Andino S.A.

In the case of Peru, the railway corridor will only include $340 \mathrm{~km}$ in its territory, though the greatest surplus that the corridor will bring about is the development of the Port in Ilo which will mean an outstanding economic impact on the southern part of the country. 


\section{PROJECT PREPARATION}

Even though, several feasibility studies have been performed. Two of them were carried out between 2011 and 2012, that is about 10 years ago, both were financed with funds from Bolivian State. Besides that, on October 2019, an agreement between Bolivia and the Latin America Development Bank (CAF) for 3 million us \$ destined for a technical, logistics and engineering studies. One relevant aspect to be considered on these studies is the interoperability among the three countries involved in the project.

The estimated cost of this "Pharaonic Project" amounts between 10 and 15 billion us $\$$ and has already attracted the interest of international investors across the world.

\section{FUTUTRE RESEARCH}

Is in this context that the dissertation thesis will be carried out by the author of this paper, focusing on several aspects from the transport technology. In particular, a search for answer to the location of service centers; scheduling of trains and capacity assessment. The aim is to propose a methodological approach for optimization of the new infrastructure on transcontinental freight corridors in technological aspects.

\section{CONCLUSIONS}

The Bi-Oceanic Railway Corridor being in the first instance a huge engineering challenge where the Geology and the Topography will be an issue of paramount importance. At the same time, it is great endeavour for achieving a true regional integration with all advantages that the railways provide and that could be, eventually, reflected on an economic development and prosperity for our countries.

Let's hope that the "Decision Makers" will have the wisdom to assess this project above all from the technical and economic point of view and less on political bases. Having reaching a point where we need nothing but brilliant minds to anticipate a bright future.

\section{References}

ALAF. (Latin American Railway Asociation). 2003 Valuation of External Costs in Land Transport.

Ing. Rafael Echazú B. 2012. Transport from "El Mutúm” to Pacific Ports.

Bolivian Army Engineers. 2012. Change in Super Structure of Railway Lines in Bolivia.

Bolivian Ministry of Planning and Development. 2013. Preliminary Feasibility Study for a Bi-Oceanic Railway Corridor.

Bolivian Andean Railway. 1998. Operating Rules

Bolivian Oriental Railway. 1996. Freight Trains Operating Rules

Ing Jose Luis Telleria PhD. 2004. Geophysics and Geophysical Maps of Bolivia.

Doplayer.es 2010. Corridor Scheme.

Latin American Railway Association. 2008. Length of railway lines in South America.

Energy Press, Research and Documentation Center. 2005. Bolivian Railway System Map.

FC Central Andino S.A. 2009. Travel Times Scheme. Source: 